\title{
Integrating Curriculum Ideology and Politics into International Economic Cooperation Course for Cultivating International Inter-disciplinary Talents
}

\author{
Linyue Li \\ School of International Trade and Economics, Central University of Finance and Economics, Beijing, China
}

Email address:

lilinyue312@163.com

To cite this article:

Linyue Li. Integrating Curriculum Ideology and Politics into International Economic Cooperation Course for Cultivating International Inter-disciplinary Talents. Higher Education Research. Vol. 5, No. 6, 2020, pp. 236-242. doi: 10.11648/j.her.20200506.15

Received: December 2, 2020; Accepted: December 11, 2020; Published: December 16, 2020

\begin{abstract}
On the background of China's Belt and Road Initiative and regional economic cooperation model dominated by China, the research on integrating Curriculum Ideology and Politics into International Economic Cooperation course for cultivating international inter-disciplinary talents is meaningful and promising. The objective of this research is to explore the talent training mode with Chinese characteristics and Curriculum Ideology and Politics, from the aspect of Chinese-English bilingual teaching goals, Chinese-English bilingual teaching patterns, Chinese-English bilingual teaching materials, and Chinese-English bilingual teaching practices. The incorporation of Curriculum Ideology and Politics into guided teaching methods for English-Chinese bilingual teaching represents educational innovation. Using international advanced teaching strategies, the method of this research covers incorporation of Curriculum Ideology and Politics into guided teaching methods for English-Chinese bilingual teaching, incorporation of Curriculum Ideology and Politics into experiential teaching methods for Chinese-English bilingual teaching, and incorporation of Curriculum Ideology and Politics into transformational teaching methods for Chinese-English bilingual teaching. The conclusion is that the combination of Curriculum Ideology and Politics and bilingual teaching in the course on International Economic Cooperation allows higher education bilingual teaching directions in Chinese contexts to be explored. Furthermore, bilingual teaching strategies provide strong support to international talent development and positively promote the internationalization of talent. Follow-up or future work on this topic should mainly focus on the development and application of curriculum ideological and political teaching in other courses for the specific corresponding personnel training objectives.
\end{abstract}

Keywords: Curriculum Ideology and Politics, International Economic Cooperation, Moral Education, New Era, International Inter-disciplinary Talent

\section{Introduction}

To effectively implement the guidelines/guidance from the National Education Conference, fulfill the development goal of moral education, and promote the development of innovative talent as well as upgrading talent development quality, this study adopts the principles of the 19th National Congress of the Communist Party of China and "Xi Jinping Thought on Socialism with Chinese Characteristics for a New Era". The goal is to comprehensively identify the nature of moral education in students' ideological and political work and teaching in all courses. The combination of moral education and professional education enables knowledge and values to synergistically imparted, thereby forming an education framework involving all personnel, whole processes, and all courses. Parallel course teaching can function in synergy with students' ideological and political work [1]. Professional teachers should consider Curriculum Ideology and Politics as the basis to include patriotism in their teaching. Investigation of the ideological and political features and learning objectives for each course enable professional teachers to tactically incorporate ideological and political education into the whole process of talent development, convey socialist core values during knowledge dissemination, and integrate various ideological and political education elements into each segment of teaching [2]. The 
present study is subject to major challenges: the implementation of moral education under Curriculum Ideology and Politics and how currently popular teaching innovation models may be applied in Chinese-English bilingual teaching to combine theory and practice and to explore the application of transformational, experiential, and discovery-centered teaching methods proposed by foreign scholars to teaching in Chinese contexts. The aim of this study was to develop a Chinese-English bilingual model with Chinese characteristics for teaching the subject of international economic cooperation that is adapted to Chinese students and Chinese education systems.

After 40 years of Chinese economic reform, China has experienced rapid economic development and required increasing versatile international talent with Chinese-English bilingual abilities. After China joined the World Trade Organization, strategies for developing bilingual talent not only accommodated the need for international talent in China but also represented a highlight of educational reform in China. Bilingual teaching in higher education is necessary to improve the quality of contemporary Chinese university students and to develop versatile talent in the new era. Moreover, bilingual teaching is imperative for the reform of Chinese higher education and the facilitation of economic construction in China. Whether China has identified the bilingual teaching strategies conforming to Chinese characteristics during many years' exploration of bilingual teaching theory and practice and whether relevant goals have been achieved merit further consideration. Strategies to develop excellent international talent based on bilingual teaching-oriented educational reform not only accommodate the need for international talent in China but also represent a highlight of education reform in China. However, research on the model that China should adopt for bilingual teaching studies remains inadequately developed. Scholars have focused mostly on the teaching models, materials, and methods that maximize the efficacy of bilingual teaching, improve teaching quality, realize the successful transition from local to international education, and enhance students' competencies in all aspects. On the basis of these core problems and under the Belt and Road Initiative and regional economic cooperation model dominated by China, research on Chinese-English methods for teaching international economic cooperation is extremely valuable.

\section{Summary of Related Theory and Practice}

\subsection{The Theory of Curriculum Ideology and Politics}

\subsubsection{The Development History of Curriculum Ideology and Politics}

The report of the 19th National Congress of the Communist Party of China proposed the implementation of moral education and the cultivation of young people who have a good and all-round moral, intellectual, physical, and aesthetical grounding and are well-prepared to join the socialist cause. In the Conference of Ideological and Political Work of National Higher Education, General Secretary Xi Jinping stated that the consolidation of higher education is dependent on moral education, which must be considered as a cornerstone that incorporates ideological and political work into in the education process, so as to facilitate the achievement of whole-process all-direction education. Moral education is the essential mission of education, the cornerstone of higher education, and is at the core of higher education work. The connotations of new-era higher education moral education are as follows: First, the cultivation of "a new generation capable of shouldering the mission of national rejuvenation" is the fundamental goal of moral education in new-era higher education. Second, core socialist values are the fundamental rules for moral education in new-era higher education. Third, the realization of the "Chinese dream" is a much discussed topic in moral education within new-era higher education [3-7].

Higher education ideological and political work requires the construction of a context in the big picture, constituting the concept of "great ideology and politics," and all ideological and political courses should move toward Curriculum Ideology and Politics [8]. The combination of Curriculum Ideology and Politics with Chinese-English bilingual higher education is necessary for the quality and development of versatile new-era talent among contemporary Chinese university students; in addition, such combinations are imperative for the reform of Chinese higher education to improve economic construction in China. As economic globalization and higher education internationalization intensify, connections among countries strengthen. As China's openness to international trade and modernization construction continue from all aspects at multiple levels, selecting a course on International Economic Cooperation-a comprehensive course with uniquely Chinese characteristics - as the content for higher education bilingual education implementation can provide theoretical value and practical implications.

In recent years, with coordination among and persistent efforts from local educational authorities and departments as well as faculty and students of higher education, considerable progress has been made in ideological and political education at universities. The mainstream ideology of university students is positive, healthy and upward, advocating the leadership of the Communist Party of China and identifying strongly with socialism with Chinese characteristics [9]. Curriculum Ideology and Politics describes conscious and planned design of various segments of educational philosophy in ideological and political education. Through the development of an educational atmosphere and the implicit and organic incorporation of moral norms, ideology, and political concepts into the teaching process, students can develop into qualified talents able to meet the needs for national development [9]. Curriculum Ideology and Politics requires practical design and implementation support from top education authorities in addition to constant exploration and practice by teachers in moral education missions. 


\subsubsection{Application of Curriculum Ideology and Politics to International Economic Cooperation Course}

This study explored a bilingual teaching model that incorporates Curriculum Ideology and Politics into the course on International Economic Cooperation, which has Chinese characteristics, to develop a series of operable student-centered education implementation programs. Through practical application in teaching, this study explored the reformative policy of Chinese-English bilingual teaching that integrates Curriculum Ideology and Politics elements into international economic cooperation to fulfill the goals of optimizing bilingual teaching strategies and promoting excellent talent development models. The integration of advanced teaching models into international versatile talent development programs based on the Curriculum Ideology and Politics background is highly innovative. Other countries are more experienced in foreign language teaching, and many successful cases and models serve as a reference. After extensive study and observation of successful domestic and foreign experiences, we communicated with professors who attain success in bilingual teaching fields. Through a literature review, case study, questionnaire survey, classroom experiment, student-centered approach, and response survey, we carefully observed influential Curriculum Ideology and Politics teaching models at home and abroad and incorporated Curriculum Ideology and Politics elements into advanced teaching methods (e.g., massive open online courses, flipped classrooms, micro courses).

\subsection{Upgrade of Chinese-English Bilingual Education in Curriculum Ideology and Politics}

The results of the literature review and educational practices for the teaching of international economic cooperation were discussed to provide useful approaches and ideas for the improvement of bilingual teaching.

First, in consideration of the teaching model and national conditions in China, higher education students must complete various English proficiency tests. Therefore, discussing the improvement of English proficiency without the consideration of various training methods in response to English proficiency tests is impractical. To parallel the implementation of English proficiency test training and Chinese-English bilingual teaching, educators can consider establishing professional English courses to prepare students for tests by teaching them English grammar, listening, speaking, writing, and reading skills. Moreover, educators can select easy-to-learn courses with little challenge to introduce bilingual teaching. Situated learning of English was implemented in these courses.

Second, emphasis should be placed on teacher training, which functions as the basis for bilingual teaching. In "On Research and Exploration of Bilingual Teaching in Higher Education," Gao (2007) mentioned that scholars identified four fundamental criteria for bilingual teachers in the United States: a) bilingualism and bicultural identity, b) the relevant qualification certificate issued by the governmental education department, c) higher education degrees, and d) advanced professional literacy [11]. Per foreign standards, Chinese scholars have proposed quality requirements for bilingual teachers in higher education in China, including professional objectives, reasonable knowledge structure, the principles of scientific education, and versatile capabilities.

Third, the compilation of bilingual teaching materials and the selection of supplementary materials are crucial. Empirical experience exemplifies that every country successful in the promotion of bilingual education has teaching materials suitable for the country. Direct adoption of original teaching materials from other countries is apparently inappropriate in the selection of bilingual teaching materials with Chinese characteristics because some foreign teaching materials are too simple to be used as fundamental reading materials in other countries, whereas some are excessively complicated and difficult, with incomprehensible language, and are thus unsuitable for direct use in bilingual teaching in China's higher education. However, balancing the "original" message of English teaching materials and agreement with the national conditions of China in bilingual teaching in Chinese higher education, researchers must learn from Western cultures and incorporate the latest prominent research achievements of Chinese scholars into teaching materials. Simply use of foreign language teaching materials and the corresponding translated versions render teaching monotonous. In addition, foreign materials lack international economic content applied to situations in China and cases from Asian markets. Basically, no English teaching materials have managed to discuss the "Rules of Origin" that presents Chinese characteristics. Basic theory teaching materials in a foreign language are written mostly in the form of prose, exhibiting weak theoretical structure. Therefore, it is necessary to integrate the advantages in Chinese and foreign teaching materials to develop easy-to-understand higher education bilingual teaching materials being adapted for use in China and containing in-depth knowledge.

Schools or colleges must expand international exchange pathways and channels to continuously elevate bilingual education teachers' ability to reference and learn from successful domestic and foreign experiences. These exchanges and interactions increase students' experiences of foreign language contexts. As such, bilingual higher education must be developed with various global dynamics, the future, and modern science and technology taken into account.

\section{Application of International Advanced Teaching Strategies}

To support the revitalization of the Chinese economy through intellectual talent and maintain China's position as a great power, the training of international talents is the key to maintaining China's growth in international competitiveness [12]. Notably, Curriculum Ideology and Politics further extends ideological and political education and offers an optimal method, in combination with professional course 
teaching, to realize connotative development and improvement. "Combined" here means that Curriculum Ideology and Politics is not an independent course but a process that must be integrated and assimilated into concrete teaching contents and segments [9, 13-15]. Curriculum Ideology and Politics is essentially a course-related concept as opposed to a new course or activity, whereby higher education ideological and political educations are incorporated into various components and aspects of classroom teaching and reforms to realize implicit moral education.

\subsection{Incorporation of Curriculum Ideology and Politics into Guided Teaching Methods for English-Chinese Bilingual Teaching}

Compared with Western countries, the development of the guided teaching method in China occurred relatively later, yielding fewer relevant studies. Prominent relevant studies in China include the following: Luo and Song (2015), in "Research on the Guided Teaching Method in the International Financial Course," analyzed problems in course teaching and proposed guided teaching methods for international financial teaching. The core content involves effective guidance of the teacher to adequately stimulate students' active participation, excite students' interest in international finance, and promote teaching effectiveness. Zhu (2013) [17] suggested that, in finance teaching, teachers introduce various current cases related to finance in class to facilitate student discussion and interaction and, in turn, stimulate their interest and enthusiasm. Consequently, the teaching method helps each student to better understand and learn new knowledge, review learned information, and enhance their creativity. Li (2013) [18] argued that university education must involve the design of various vivid and noteworthy cases according to curricular core contents, greatly benefitting the cultivation of students' independent learning abilities and increasing their interest in learning. Zhou et al. (2012) [19] suggested that teachers design guided problems according to various scenarios during teaching processes, especially news reports related to the course and popular issues. Such designs provide students with opportunities to apply acquired theory and knowledge in practice, think practically, and seek solutions. This approach is conducive to in-depth understanding of knowledge.

The incorporation of Curriculum Ideology and Politics into guided teaching methods for English-Chinese bilingual teaching represents educational innovation. The applied methods and contents of guided teaching include the following: a). The case-guided teaching method refers to the use of problem-based methods throughout the teaching process; questions related to the case are proposed to guide active thinking among students. Before the class, teachers prepare the classes and combine course contents to establish case problems for consideration in class. During lecture sessions, teachers ask questions according to the course content and request that the students discuss the questions in groups. Students are encouraged to participate in brainstorming and to inspire and correct one another during discussion. Teachers then systematically summarize the discussion outcomes and highlight points for improvement accordingly [16]. b) The principles and course design patterns in problem-based teaching are highly similar to those for the case-guided teaching method. c) Interest-guided teaching involves instructing students to independently search for information and complete in-depth analysis reports on topics that have attracted widespread attention and that interest them, such as the contagion effects of financial crises and foreign exchange control.

\subsection{Incorporation of Curriculum Ideology and Politics into Experiential Teaching Methods for Chinese-English Bilingual Teaching}

Integration of experiential teaching methods with entrepreneurial education can be applied in Chinese-English bilingual teaching in the international economic cooperation course such as in service marketing, international management, international business, and entrepreneurship. The active application of experiential teaching into these fields enables students to acquire domain knowledge, interpersonal skills, social skills, decision-making abilities, and problem-solving abilities through service-marketing courses, on-site visits (e.g., to Auckland Zoo and to Lantern Festival), interaction with industrial experts (communications in the zoo and marketing management), and experiential learning methods based on group reflection, for example. In international management courses, experiential teaching methods can be used to realize cultural experiences through food, language, and interaction with people from diverse cultural backgrounds. Through negotiation, the experiential process of role play is implemented. In business courses, Dr. Manisha Karia and Dr. Hanoku Bathula cooperated to develop an experiential learning method realized by an international virtual team composed of 6,000 students of 80 universities from 43 countries.

In the entrepreneurial education field, experiential bilingual teaching methods can maximize the effectiveness of bilingual teaching strategies and promote development goals for the cultivation of talent. First, entrepreneurial education is a possible career choice. Entrepreneurial education includes entrepreneurship and employment, fortune creation, youth development, the construction of harmonious society, and the promotion of economic development [20]. However, the implementation of bilingual entrepreneurial teaching may be subject to a series of challenges in class such as cultural diversity, overemphasis on theoretical teaching and classroom lectures, and limited funds. Entrepreneurial education can be generally divided into group and individual entrepreneurial education. Group entrepreneurial education can be realized through classroom learning and hands-on practical projects, of which the outcomes can be evaluated by test scores and business plan. During the group entrepreneurial education process, the development of entrepreneurial thinking and entrepreneurship involves "The 
opportunity basket — creative thinking," "inspiring stories," and speeches by entrepreneurs sharing their life stories. In addition, bilingual teachers instruct students in experiential activities. Students start by writing business plans, using various textual materials and templates, inviting guest speakers (e.g., loan managers of banks), visiting commerce fairs, and watching Dragon's Den (a documentary television program similar to "Win in China"). Individual entrepreneurial education involves counseling at microscopic levels. Specifically, the teaching may include one-on-one supervision. Each student composes business plans for a business opportunity. Using guidelines and comparisons of business plans as well as primary and secondary data, students analyze market competition. In summary, the advantages of experiential bilingual teaching methods are the development of self-efficacy for entrepreneurship, acquisition of commercial knowledge and skills, acquisition of abilities to independently conduct scientific research, and construction of interpersonal networks, improved time management skills, improved verbal and writing-based communication abilities, and decision-making and problem-solving abilities that translate to practical contexts.

Furthermore, experiential teaching methods can be implemented by allowing students to participate in the test design of bilingual teaching courses so the students can empathize with teachers' comprehension of the entire knowledge system and methodical thinking processes during test design. The test method known as the "three $z h i$ (self or autonomy) model,"-namely, autonomous proposition, self-testing, and self-evaluation-proposed by Lu Guodong, a nationally renowned teacher was adopted for education reform. Active participation in experiential teaching that stimulates subjective agency changes the traditional bilingual teaching model and increases interest in learning.

\subsection{Incorporation of Curriculum Ideology and Politics into transformational Teaching Methods for Chinese-English Bilingual Teaching}

The integration of Curriculum Ideology and Politics into transformational teaching is an innovative improvement to Chinese-English bilingual teaching. The first transformational strategy is to instruct students to overcome difficulties. Student-centered classrooms indeed require more lesson preparation than do teacher-centered classrooms. Students are encouraged to seek peer assistance and use the Internet or WeChat groups to facilitate learning. The second transformational strategy is considering what students and teachers can obtain from the teaching process. For example, the course on international economic cooperation helps students to gain confidence in dealing with international finance-related changes in their personal lives and careers. Correlated with the learning goal, this skill is the most critical to learning in the course. The third transformational strategy is the conflict between challenge and reason. Students are encouraged to step outside their comfort zones to increase learning opportunities. Challenges that teachers pose to students often stimulate learning behavior. Teachers encourage students to express, debate, and listen to contrasting viewpoints. The fourth strategy is creating fulfilling and engaging learning experiences. Mini lectures, group discussions, movie teaching, student demonstrations, game-based learning, and other methods are employed to provide students with experiences that exceed textbook knowledge. The fifth transformation strategy is providing more alternatives for students; this strategy helps students improve their learning outcomes. The sixth transformational strategy is translating into practical experience, such as requesting students to engage in internships with and without remuneration or credits and short-term internships, to complete alternative forms of homework, to solve workplace problems encountered by professors and students, and to accomplish homework on the creation of cases. The seventh transformational strategy involves the use of learning journals, learning assessments, and one-minute memoranda to encourage student reflection and self-evaluation.

Course development in bilingual teaching centers mostly on international topic-related disciplines such as international economics, international finance, international trade practice, and international commerce negotiation. Centering on these courses introduced from the Western economic system, such international literacy can be extended into other disciplines in multiple dimensions and adapted to the national conditions of China to develop international talent training programs with Chinese characteristics. Accordingly, international elements can serve as a bridge between bilingual teaching and international talent development.

First, to ensure the successful development of bilingual teaching, appropriate Chinese-English teaching materials are a crucial prerequisite. Taking the international economic cooperation Chinese-English bilingual teaching from the China-Australia Program as an example, we selected original English teaching materials and supplementary data provided by Australia to fully exploit high-quality teaching resources from outside of China, access information in its original forms, and experience authentic modes of expression in English. In general, the original English teaching materials convey knowledge through flexible and adaptable contents with highly readable text, adequate numbers of cases, and appropriate illustrations. Therefore, the original English teaching materials more readily excite students' learning interest. However, because the original English teaching materials are unsuitable for China's national context, some of the contents cannot be directly used as bilingual teaching materials in higher education. Accordingly, the selection of teaching materials as well as whether bilingual teachers should use their own materials to replace the original teaching materials becomes an imperative problem. In the selection of bilingual teaching materials for the course on international economic cooperation, international and Chinese characteristics must both be preserved to maintain international talent development principles. The original English teaching materials focus on the balance between theory and case studies, and encompass wider content scopes. 
By contrast, Chinese teaching materials focus on logical and test-based learning methods [21]. According to teaching feedback and results, the adjustment of teaching contents requires that foreign teaching materials be applied to China's national context with their advantages being retained. Bilingual teachers should reference original teaching materials during the teaching process and develop corresponding Chinese-English teaching materials by combining their personal experiences of studying abroad, academic backgrounds, and work practices to the development of economics curricula adapted to the national context and content regulations of China, thereby guaranteeing the successful connection of knowledge points.

Second, an analysis of the level of internationalization of bilingual teachers shows that study abroad by these teachers represents the core element of bilingual teaching: Teachers who have studied abroad exhibit significantly greater competence in bilingual teaching practices than do teachers who have not; bilingual teachers who have studied abroad have greater access to international knowledge and relevant international interpersonal resources. To enhance internationalization and teaching quality among bilingual teachers, various types of training can be implemented for bilingual teachers to continuously increase the quality of teaching and levels of internationalization in their teams. Higher education institutes can send selected teachers to attain further education abroad, especially in countries with cooperative education agreements. This approach benefits bilingual teachers' understanding and learning of advanced course teaching concepts and models adopted by the foreign cooperative institutes. In addition, higher education institutes can directly hire excellent bilingual teachers with extensive professional knowledge and a high level of English proficiency to implement bilingual teaching, continuously enriching the bilingual teaching faculty team and elevating the teachers' levels of internationalization [22].

\section{Conclusion and Policy Implication}

In summary, the transformational effects and value of combining Curriculum Ideology and Politics and ChineseEnglish bilingual teaching to the strategic development of international talent cannot be overemphasized. In the current level of bilingual teaching and international talent development, the elevation of bilingual teaching quality considerably promotes the internationalization of professional education and strategies for international talent development. Furthermore, bilingual teaching strategies provide strong support to international talent development and positively promote the internationalization of talent. Many internationalization elements and contents related to international talent development strategies are involved in the process of bilingual teaching implementation, an advanced teaching concept. Therefore, improving bilingual teaching quality effectively prompts the advancement of international talent development strategies. In addition, the memorization of professional English terminology increases students' vocabulary size in communications, engendering versatile, internationally competitive talent with extensive professional knowledge. Conversely, the advancement of international talent development strategies may affect bilingual teaching philosophy and provide tremendous drive to the implementation of bilingual teaching. When the extension and intention of international talent development strategies advance, the corresponding bilingual teaching practices are activated, which in turn enhances the philosophy and standards of bilingual teaching, clarifies the goals of bilingual teaching, and enables the bonds between bilingual teaching and talent internationalization to be strengthened.

Per the aforementioned observations, the combination of Curriculum Ideology and Politics and bilingual teaching in the course on International Economic Cooperation allows higher education bilingual teaching directions in Chinese contexts to be explored. Bilingual teachers in higher education should actively cooperate with students, allowing both parties to develop and complement each other during the teaching and learning processes. In addition, a combination of the practical style of Chinese higher education and the romantic style of foreign higher education that that considers individual learning styles facilitates the organic assimilation of "teach more learn less" of Chinese education and "teach less learn more" of foreign education. With bilingual teaching functioning as a bridge, teaching models and methods in China and other countries may be integrated thoroughly. Elective courses are thus established to enable progressive breakthroughs in educational philosophy, teaching methods, and development models. We believe that excellent faculty teams adroit in professional knowledge and English communication skills with a strong passion for bilingual teaching and university students who recognize and accept bilingual teaching will play major roles in educational reform. Follow-up or future work on this topic should mainly focus on the development and application of curriculum ideological and political teaching in other courses for the specific corresponding personnel training objectives.

\section{Acknowledgements}

This research project is funded by the 2019 "Hongseqing Longmaxing" Teacher "Ideological and Political Plus" project of the Central University of Finance and Economics (SZJ1904), and Academic Reform Project by School of International Trade and Economics (GMJG2018024).

\section{References}

[1] Pang, J. J. (2019). Be the Active Promotor and Leader of New-Era Moral education. Leading Journal of Ideological and Theoretical Education, 1, 9-10.

[2] Wang, X. L. (2019). Ideology About Advanced Promotion of Cultural Education in New-Era Higher Education. Beijing Education (Moral Education), 1, 33-36. 
[3] Yang, Y. Q. (2019). Several Understandings on the Ideological and Political Construction of Curriculum. Journal of Beijing College of Politics and Law, 4, 109-112.

[4] Chang, Q. \& Han, X. P. (2019). Construction of Coordination Mechanism for Systematic Implementation of Moral education: Analysis based on Survey Data of 12 Higher Education Institutes. Jiayu Yanjiu (Educational Research), 40 (1), 94-101.

[5] Tian, H. S. (2019). Questions that Should be Paid with Extensive Attention for New-Era Innovative Talent Cultivation Models. Journal of the Chinese Society of Education, 1, 43-45.

[6] Hu, X. H. (2018). Moral education: Competing to be the "Great Master" of New Era. Moral Education China, 22, 11-12.

[7] Shi, G. L. (2018). Strategic Requirements for Implementing Fundamental Tasks of Moral education in the New Era. China Higher Education, 22, 9-11.

[8] Xiao, X. L. \& Zhu, Z. (2018). Exploration and Practice of Ideological and Political Theory Teaching in All Courses under the Framework of "Great Ideology and Politics." Leading Journal of Ideological and Theoretical Education, 10, 133-135.

[9] Tian, H. F. \& Fu, H. (2018). Ideological and Political Education in Curriculum: Practical Ways of Ideological and Political Education's Integration into Specialized Course Teaching in Universities. Future and Development, 42 (4), 99103.

[10] Gao, Y. Z. (2007). On Research and Exploration of Bilingual Teaching in Higher Education. Popular Science and Technology, 1, 159-161.

[11] Yang, S. G. \& Dai, Y. (2005). New Progress of Domestic Bilingual Teaching Research in China. Shanghai Research on Education, 8, 48-52.

[12] Liu, X. L., Huang, L. Y., \& Wang, J. T. (2012). Project for Internationalized Personnel Scheme: a Case Study on major of international economy and trade. Journal of Dalian Nationalities University, 4, 409-411.
[13] He, H. J. (2017). Internal Logic and Construction Strategies of Development from Ideological and Political Courses to the teaching of Ideological and Political Theories in All Courses. Ideological and Political Education Research, 5, 60-64.

[14] Li, G. J. (2017). Five Key Segments in Construction of Ideological and Political Theory Teaching in All Courses. China Higher Education, 3, 28-29.

[15] Gao, D. Y. \& Zong, A. D. (2017). From Ideological and Political Courses to the teaching of Ideological and Political Theories in All Courses: Constructing Higher Education Ideological and Political Education Curricula on a Strategic Altitude. China Higher Education, 1, 43-46.

[16] Luo, D. C. \& Song, L. C. (2015). Research on the Guided Teaching Method in the International Financial Course. Continue Education Research, 8, 110-112.

[17] Zhu, E. Q. (2013). Financial Discipline Case-based Teaching Status, Problems, and Solutions in China. Modern University Education, 3, 108-111.

[18] Li, H. M. (2013). "Observation and Implications of Case-based Teaching in Teachers' On-site Teaching. China University Teaching, 6, 70-72.

[19] Zhou, J. X., Zhang, W. M., Du, X. Y., \& Luo, P. F. (2012). Application of the Seminar-style Teaching Method in Three-Hour Teaching Sessions. China University Teaching, 7, $57-59$.

[20] Sofoluwe, A. O., Shokunbi, M. O., Raimi, L. and Ajewole, T., Enterpreneurship education as a strategy for boosting human capital development and employability in Nigeria: Issues, prospects, challenges and solutions. Journal of Business Administration and Education, Vol. 3, No. 1, January 2013, pp. 25-50.

[21] Jiang, A. Y. \& Cui, Y. N. (2013). Improvement of International Economics Bilingual Teaching Methods. Journal of Shandong Technology and Business University, 2, 104-107.

[22] Yang, H. P. (2012). Economics Bilingual Teaching in ChinaAustralia Cooperative Education. Journal of Educational Institute of Jilin Province, 11, 39-40. 